Winter 2006

\title{
The New Politics of Linkage: India's Opposition to the Worker's Rights Clause
}

\author{
Kevin Kolben \\ Rutgers Business School
}

Follow this and additional works at: https://www.repository.law.indiana.edu/ijgls

Part of the International Law Commons, and the Labor and Employment Law Commons

\section{Recommended Citation}

Kolben, Kevin (2006) "The New Politics of Linkage: India's Opposition to the Worker's Rights Clause," Indiana Journal of Global Legal Studies: Vol. 13 : Iss. 1 , Article 8.

Available at: https://www.repository.law.indiana.edu/ijgls/vol13/iss1/8

This Symposium is brought to you for free and open access by the Law School Journals at Digital Repository @ Maurer Law. It has been accepted for inclusion in Indiana Journal of Global Legal Studies by an authorized editor of Digital Repository @ Maurer Law. For more information, please contact rvaughan@indiana.edu.

\section{$\Psi$}

JEROME HALL LAW LIBRARY

INDIANA UNIVERSITY

Maurer School of Law
Blooming ton 


\title{
The New Politics of Linkage: India's Opposition to the Workers' Rights Clause
}

\author{
Kevin KOLBEN*
}

\begin{abstract}
This article examines why India has opposed a World Trade Organization (WTO) workers' rights clause, and calls for a new way of thinking about international institutions and the link between trade and labor rights. Many labor rights supporters argue that labor rights principles should be integrated into the WTO, either via the addition of a workers' rights clause or through a "judicial" reading of labor rights values into the existing WTO framework. But India has led a large block of developing countries in opposing any link between labor rights and the WTO. This opposition has been based primarily on economic arguments that suggest linkage is motivated by protectionism, concerns about political sovereignty and neocolonialism, and structural arguments about the proper institutional roles of the ILO and WTO. These arguments, it is suggested, must be understood in both a contemporary and historical context. In light of this opposition by developing countries, the article proposes a transition from a WTO-centered view of trade and labor linkage to a paradigm based on bilateral and regional market-based agreements that utilize the ILO a model that would engage more dynamically with the concerns presented by India and other stakeholders in the developing world.
\end{abstract}

\section{INTRODUCTION}

Efforts to link workers' rights and trade through a workers' rights clause in the World Trade Organization (WTO) have, for the foreseeable future, failed. ${ }^{1}$

*Assistant Professor, Rutgers Business School. J.D. 2002, M.A. (South Asian Studies) 2002, University of Michigan; B.A. 1994, Oberlin College. I would like to thank Wayne Eastman, Ashwini Sukthankar, and the participants of the 13th Annual Conference of the Indiana Journal of Global Legal Studies: Globalization and the New Politics of Labor (Indiana University School of Law-Bloomington, February 11-12,2005) for helpful comments on this paper. I would also like to thank Jayati Lal for comments on an earlier version, and Rohini Hensman for helpful conversations and guidance while conducting research in India. Any errors are, of course, my own.

1. I will use the terms "workers' rights clause" and "social clause" interchangeably. While the term "social clause" is the preferred term in the Indian context, "workers" rights clause" is more commonly used in the United States and among labor rights advocates. 
This state of affairs is due in no small part to oppositional efforts by the WTO's block of developing countries, particularly India, to link trade and labor. Particularly surprising to Western workers' rights advocates has been the opposition by stakeholders in some countries of the developing world who might have been considered natural allies, such as unions and labor rights advocates. Yet scholars have spent insufficient time either categorizing the underlying arguments for this opposition or devising new linkage regimes that constructively engage with and respond to these arguments.

In the trade and labor debate, a new way of thinking about international institutions and the linkage question is required. Therefore, in this article I use India as a case study to ask why many developing countries opposed such a clause, and argue that labor and trade advocates ought to look to non-WTOcentered trade and labor rights regimes in considering the role of labor rights in the international trading order. An explicit engagement with these issues is key if the labor and trade question is to move from a politics of opposition, toward a politics of the realizable.

In Part I, I provide context to the debate and briefly map out some of the mechanisms proposed by scholars and activists to link trade and labor rights. In Part II, I look at the history of India's opposition to the workers' rights clause from the mid-1990s until just after the Seattle WTO Ministerial in 1999. I describe and categorize the prominent arguments and rhetoric that were used in the public discourse on the issue roughly during the time in question, and place them in historical context. I conclude in Part III by proposing that a new politics of linkage moves the locus of analysis away from the WTO, and toward bilateral and regional pacts that make use of the International Labour Organization (ILO) to facilitate incentives-based systems that utilize the market for labor standards.

\section{International Labor Standards and the Linkage Question}

\section{A. Justifications for International Labor Standards}

The question of whether to link trade and labor is a subquestion within the broader debate about international labor standards (ILS). The fundamental question that underpins the ILS debate is whether there should be a universally applicable set of labor norms to which all countries should adhere. Contemporary arguments for ILS and, by extension, trade and labor linkage, are generally premised on the following justifications: economic, regulatory, and human 
rights. ${ }^{2}$ Arguments based on economic justifications rest on the notion that free trade leads to negative welfare outcomes for workers in developed countries who will lose jobs to workers in the developing world. ${ }^{3}$ In other words, trade without universal regulatory ground rules constitutes a form of unfair competition or "social dumping." ${ }^{\prime 4}$ Regulatory arguments suggest that free trade without international standards will weaken human rights and labor rights protections in a regulatory "race-to-the-bottom" in which countries compete with each other for investment by curtailing workers' rights or weakening labor standards. ${ }^{5}$ Arguments based on human rights contend that all workers share universal and inalienable rights, some of which are specific to the workplace. ${ }^{6}$ Some scholars have argued that while economic and regulatory arguments are not empirically or morally persuasive, human rights are a compelling reason to link trade and labor rights. ${ }^{\prime}$

2. Michael Trebilcock has categorized these as "unfair competition," "race-to-the-bottom," and "human rights." See Michael J. Trebilcock, International Trade and International Labour Standards: Choosing Objectives, Instruments, and Institutions, in International Economic Governance and Non-Economic Concerns 289, 294-99 (Stefan Griller ed., 2003).

3. See id. at 294-96.

4. Id. at 294. Scholars are particularly skeptical of these arguments on the grounds that they are not well supported by empirical evidence. See id. at 295 ("There is almost no evidence that the reduction in relative earnings of unskilled workers in developed countries that is reasonably attributed to increased trade with developing countries relates to non-compliance with core labour standards rather than simply lower wages."); Andrew T. Guzman, Essay, Trade, Labor; Legitimacy, 91 CAL. L. Rev. 885, 892 n.28 (2003) (citing empirical evidence suggesting that the "feared wage effect would be small, and perhaps nonexistent"); Robert J. Flanagan, Labor Standards and International Competitive Advantage, in International Labor Standards: Globalization, Trade, and Public Policy 15, 16 (Robert J. Flanagan \& William B. Gould IV eds., 2003).

5. See Christopher McCrudden \& Anne Davies, A Perspective on Trade and Labor Rights, $3 \mathrm{~J}$. INT'L Econ. L. 43, 49 (2000) (suggesting that the empirical merits of the race-to-the-bottom arguments are not definitive); Kimberly Ann Elliott \& Richard B. Freeman, Can Labor Standards Improve Under Globalization? 74 (2003) (arguing that while too much reliance is placed on race-to-thebottom arguments by their advocates, globalization enthusiasts too quickly dismiss these arguments given "the fact that there are trade-related violations of core labor standards"). Contra Guzman, supra note 4, at $892 \mathrm{n} .28$ (dismissing race-to-the-bottom arguments as unfounded).

6. James Gross has emphasized the notion that workers' rights are human rights, noting "there is no compelling reason ... to continue this unrealistic separation of rights that distinguishes between violations caused by a tyrannical government and violations caused by tyrannical forces in an economic system." James A. Gross, A Long Overdue Beginning: The Promotion and Protection of Workers' Rights as Human Rights, in Workers' Rights as Human Rights 1, 4 (James A. Gross ed., 2003).

7. See, e.g., Guzman, supra note 4, at 892 ("The more persuasive justification for the use of trade sanctions against countries with poor labor practices is based on the claim that some set of labor rights are human rights that exist independently of national boundaries."); Trebilcock, supra note 2, at 299 ("[A] linkage between trade policy and such labour standards is not only defensible but arguably imperative."). 
Defining the substance of these standards is a matter of contention. Some argue that the ILO's Declaration of Fundamental Principles and Rights at Work ${ }^{8}$-in which four core areas are privileged: freedom of association, regulations on child labor, freedom from discrimination, and freedom from forced labor-ought to form the core of an international labor rights regime. Others, such as Philip Alston, argue that the move to core labor standards undermines the larger human rights project that underpins the ILS movement. ${ }^{9}$ Indeed, the lack of clarity or agreement on the contents of ILS leads to difficulties in arriving at a consensus on a linkage regime among affected countries and stakeholders. For example, it is unclear whether ILS would mandate material standards that impose costs such as a minimum wage, or would solely guarantee rights-oriented processes such as freedom of association. ${ }^{10}$

\section{B. Trade and Labor Linkage}

The desire to find a means to encourage adoption and enforcement of labor standards beyond voluntary, ILO-centered mechanisms has led many ILS proponents to campaign for linking trading privileges with adherence to ILS." The linkage debate, as Steve Charnovitz has noted, ${ }^{12}$ is not a new one, and can be traced to the beginning of the ILS movement that was launched by European social reformers in the middle of the nineteenth century. ${ }^{13}$

8. Int'l Labour Org., Declaration on Fundamental Principles and Rights at Work (1998), available at http//www.ilo.org/dyn/declaris/DECLARATIONWEB.static_jump?var_language= EN\&var_pagename $=$ DECLARATIONTEXT.

9. See Philip Alston \& James Heenan, Shrinking the International Labor Code: An Unintended Consequence of the 1998 ILO Declaration on Fundamental Principles and Rights at Work?, 36 N.Y.U. J. INT'L L. \& Pol. 221, 223-24 (2004); Philip Alston, 'Core Labour Standards' and the Transformation of the International Labour Rights Regime, 15 EUR. J. INT'L L. 457, 461 (2004).

10. See McCrudden \& Davies, supra note 5, at 51.

11. Scholars have also attempted to grapple more theoretically with the linkage question, seeking, for example, to develop more theoretical frameworks to determine when an issue might be legitimately linked with trade. See, e.g., David W. Leebron, Linkages, 96 AM. J. INT'L. L. 5 (2002); Sungjoon Cho, Linkage of Free Trade and Social Regulation: Moving Beyond the Entropic Dilemma, 5 CHI. J. INT'L L. 625 (2005) (arguing that to overcome the free trade versus social regulation debate there needs to be a synergistic approach to linkage within the WTO in which a range of institutional strategies are utilized).

12. Steve Charnovitz, The Influence of International Labour Standards on the World Trading Regime: A Historical Overview, 126 InT'L LaB. Rev. 565, 565 (1987).

13. John W. Follows, Antecedents of the International Labour Organization 10 (1951); Virginia A. Leary, Workers Rights and International Trade: the Social Clause (GATT, ILO, NAFTA, U.S. Laws), in 2 Fair Trade and Harmonization 177 (Robert E. Hudec \& Jagdish N. Bhagwati eds., 1996). 
The first legislative linkage between trade and labor came into effect in the 1890s, when the U.S. and British governments unilaterally enacted measures banning the import of products made with convict labor. ${ }^{1+}$ Efforts to link trade and labor within a multilateral framework began as early as the 1940s, when trade unions in the United States and Britain called for an international treaty prohibiting the movement of goods made in violation of labor standards such as the right to organize, the prohibition on child labor, minimum wages, and minimum hours of work. ${ }^{15}$ The first opportunity to make this a reality materialized in 1947 during the attempted formation of the International Trade Organization (ITO), the unrealized precursor to the WTO. The charter of the ITO included a clause requiring member countries to "take whatever action may be appropriate and feasible to eliminate [unfair labor] conditions within its territory." 16 The ITO failed, and its eventual successor, the General Agreement on Tariffs and Trade ${ }^{17}$ (GATT), contained no explicit provision regarding labor rights apart from a provision in Article XX, the general exceptions clause, which permitted restrictions on the importation of goods made with prison labor. ${ }^{18}$ In 1953, the U.S. government attempted to remedy this perceived labor rights deficit by proposing a labor rights provision be made part of GATT, stating that unfair labor standards "create difficulties in international trade which nullify or impair benefits under this Agreement." 19 This attempt failed as well.

\section{Unilateral Trade and Labor Measures}

While efforts to incorporate a workers' rights clause in the international trading regime proved fruitless, the United States and European countries responded by implementing a range of unilateral trade laws that conditioned special trading benefits upon respect for internationally recognized workers' rights. In addition to the prohibitions noted above on importation of products made with prison and forced labor,,$^{20}$ the United States and the European Community (EC) have also in-

14. Charnovitz, supra note 12 , at $569-70$.

15. Id. at 575 .

16. United Nations Conference on Trade and Employment, Mar. 24, 1948, Final Act: Havana Charter for an International Trade Organization art. 7, para. 1, U.N. Doc. E/CONF.2/78.

17. General Agreement on Tariffs and Trade, Oct. 30, 1947, 61 Stat. A-11,55 U.N.T.S. 194.

18. See Trebilcock, supra note 2, at 294-96.

19. Charnovitz, supra note 12, at 574 (quoting U.S. Comm'n on Foreign Econ. Policy, Staff PAPERS 437-38 (Feb. 1954)).

20. See 19 U.S.C. $§ 1307(2000)$. 
cluded labor rights conditionality in their Generalized System of Preferences (GSP) regimes. ${ }^{21}$ GSP laws are exceptions to WTO nondiscrimination rules, which permit developed countries to extend preferential and differential treatment to developing countries. This treatment takes the form of special tariff rates below the bound rates negotiated in the WTO, which are extended to beneficiary countries.

In addition to the GSP measures, the United States has incorporated labor rights language similar to that of the GSP into a range of region-specific unilateral trade legislation, including the Caribbean Basin Initiative, the African Growth and Opportunities Act, and the Andean Trade Preferences Act, as well as investment guidelines for the Overseas Private Investment Corporation. ${ }^{22}$

India and other developing countries are not enamored with conditionality in the GSP, however, which reflects their general opposition to linking what they consider to be nontrade issues with trade legislation. In 2002, India launched an unsuccessful challenge to the EC's conditionality structure, zeroing in on its requirement that countries effectively enforce antidrug laws. India had originally also included in its challenge the EC's labor rights and environmental conditionality provisions, but later amended its complaint to challenge only the drug provisions. In 2004, the WTO's A ppellate Body upheld the legality of the conditionality regimes, overturning a contrary finding by the dispute settlement panel. ${ }^{23}$

21. The U.S. GSP law requires the President, in determining whether to designate any country as a beneficiary developing country, to take into account "whether or not such country has taken or is taking steps to afford to workers in that country ... internationally recognized worker rights." 19 U.S.C. $\$ 2462$ (c)(7) (2000). "Internationally recognized rights" is defined to include: "(A) the right of association; (B) the right to organize and bargain collectively; (C) a prohibition on the use of any form of forced or compulsory labor; (D) a minimum age for the employment of children, and a prohibition on the worst forms of child labor ... ; and (E) acceptable conditions of work with respect to minimum wages, hours of work, and occupational safety and health." 19 U.S.C.A. $\$ 2467(4)$ (West Supp. 2005). For a fuller description of the history of the GSP regime, see generally Lance Compa \& Jeffrey S. Vogt, Labor Rights in the Generalized System of Preferences: A 20-Year Review, 22 Comp. Lab. L. \& Pol'y J. 199 (2001).

22. For a critique of these unilateral measures, see Philip Alston, Labor Rights Provisions in U.S. Trade Law: "Aggressive Unilateralism"?, in Human Rights, Labor Rights, and International Trade 71 (Lance A. Compa \& Stephen F. Diamond eds., 1996).

23. See Appellate Body Report, European Communities: Conditions for the Granting of Tariff Preferences to Developing Countries, If 190, WT/DS246/AB/R (Apr. 7, 2004), available at http:// www.wto.org/english/tratop_e/dispu_e/246abr_e.pdf. For background on the issue and an argument in favor of the legality of GSP conditionality, see Robert Howse, India's WTO Challenge to Drug Enforcement Conditions in the European Community Generalized System of Preferences: A Little Known Case with Major Repercussions for "Political" Conditionality in US Trade Policy, 4 CHI. J. INT'L L. 385 (2003). 


\section{Bilateral and Regional Agreements}

A turning point in attempts to incorporate a workers' rights clause into the WTO was the inability at the 1999 WTO Ministerial meeting in Seattle to make any progress on the issue, primarily due to the opposition of India and other developing countries. ${ }^{2+}$ Since this failure in Seattle, the United States has increasingly negotiated labor rights provisions into bilateral trade agreements with its trading partners. Congress incorporated language into the U.S. Bipartisan Trade Promotion Authority Act of 2002,,$^{25}$ directing the president to negotiate labor rights provisions directly into bilateral trade agreements. ${ }^{26}$ Labor rights provisions now exist in a number of bilateral agreements including, inter alia, agreements with Cambodia, ${ }^{27}$ Jordan, Chile, Singapore, Bahrain, Argentina, Australia, Morocco, and several Central American Countries in the form of CAFTA. ${ }^{28}$ Of these agreements, however, only the agreement with Jordan applies the same set of remedies to labor rights violations as to commercial breaches of the agreement. The provisions in the other agreements generally require each trading partner to enforce its own labor laws and forbid nonenforcement of each other's labor laws in order to gain a trade advantage..$^{29}$ One innovative exception to this model is the agreement with Cambodia, and I will briefly elaborate on this in Part III.

The North American Free Trade Agreement (NAFTA), a regional trade agreement, includes the now infamous labor side agreement, the North Ameri-

24. See infra Part II.D.

25. Trade Act of $2002 \S 2102,19$ U.S.C. $\S 3802$ (2002).

26. The extent to which the president is required to do this, and the form these provisions are to take, is a matter of debate and is expertly addressed in this volume by Carol Pier. See Carol Pier, Workers' Rights Provisions in Fast Track Authority, 1974-2007: An Historical Perspective and Current Analysis, 13 Ind. J. Global Legal Stud. 77 (2006).

27. See infra note 159 and accompanying text. See, e.g., Kevin Kolben, Trade, Monitoring, and the ILO: Working to Improve Conditions in Cambodia's Garment Factories, 7 Yale Hum. RTs. \& Dev. L.J. 79 (2004). The labor rights provisions in the Cambodia agreement, which is specific to the textile sector, differ substantially from the provisions in the other agreements.

28. Pier, supra note 26.

29. See Thomas Greven, Social standards in Bulateral and Regional Trade and Investment Agreements: Instruments, Enforcement, and Policy Options for Trade Unions 30-31 (Friedrich-Ebert-Stiftung, Dialogue on Globalization Occasional Papers Series No. 16, 2005). For an analysis and critique of U.S. trade policy regarding labor rights provisions in free trade agreements, see Marley S. Weiss, Two Steps Forward, One Step Back-or Vice Versa: Labor Rights Under Free Trade Agreements from NAFTA, Through Jordan, via Chile, to Latin America, and Beyond, 37 U.S.F. L. Rev. 689 (2003). 
can Agreement on Labor Cooperation (NAALC). ${ }^{30}$ The provisions of this side agreement have come under tremendous critique, and many now agree that its provisions are too weak, poorly designed, and do not serve as a good model for linkage. ${ }^{31}$ While a number of complaints were filed by parties using the NAALC mechanisms, these complaints have largely met with little success. Some also suggest that these provisions were mostly intended to be a hollow means to diffuse the labor-activist opposition to trade agreements. As economist and linkage opponent Robert Stern has noted, "The side-agreement process might thus be viewed as a convenient political expedient to placate U.S. labor activists while at the same time avoiding confrontation with NAFTA partners over the use of trade sanctions." 32

Yet despite their weaknesses in practice, bilateral and regional agreements have the advantage of being politically negotiated agreements that have the direct consent of their signatories. Because they are negotiated in a specific context, they provide an opportunity to avoid "one-size-fits-all" solutions to the linkage question and allow for more varied and experimental approaches to protecting workers' rights.

\section{The WTO}

While the United States and, to a lesser extent, the EC have incorporated labor rights language into unilateral and bilateral trade regimes, efforts to link trade and labor through a workers' rights clause in the WTO have been unsuccessful. Trade unions have often been at the forefront of these campaigns, and the International Confederation of Free Trade Unions (ICFTU) has taken the

30. The North American Agreement on Labor Cooperation (NAALC) provides for an elaborate mechanism by which the three signatory countries-Canada, the United States, and Mexico-can file complaints with country contact points to claim that a signatory country had failed to enforce its own domestic labor law. Each country agrees to "ensure that its labor laws and regulations provide for high labor standards" and to "strive to improve those standards," referring to ILO core labor standards and U.S. internationally recognized labor standards. North American Agreement on Labor Cooperation, U.S.-Can.-Mex., Sept. 14, 1993, 32 I.L.M. 1499. A rather complex enforcement system is established that provides for consultations between parties, evalu ations of the complaint, and, as a final instance, dispute resolution. Id.

31. See generally Weiss, supra note 29 , at 701-11.

32. Robert M. Stern, Labor Standards and Trade Agreements 16 (Univ. of Mich. Gerald R. Ford Sch. of Pub. Policy, Working Paper No. 496, 2003), available at http://www.fordschool.umich.edu/ rsie/workingpapers/Papers476-500/r499.pdf. 
lead on promoting trade and labor linkage. ${ }^{33}$ However, as Charnovitz has noted, these efforts have lacked continuity, each time appearing to be a reinvention of the wheel. ${ }^{34}$

If and how labor rights ought to be included in the WTO framework is a matter of debate. Some argue for a workers' rights clause, i.e., a separate labor rights provision incorporated directly into the WTO. Chantal Thomas has described this as a "legislative" approach to linkage. ${ }^{35}$ Unions and labor rights activists have been some of the most fervent advocates of the legislative approach, and the ICFTU, in 1999, published its own workers rights' clause proposal in anticipation of the Seattle Ministerial. ${ }^{36}$ The ICFTU proposed that the ILO work dynamically with the WTO to determine whether a country is in violation of core labor rights. If a violation occurs, an escalating set of punitive measures might be applied, although these are left intentionally vague. ${ }^{37}$ The approach proposed by the ICFTU exemplifies the model that is most closely associated with the workers' rights clause in the popular mindset, including in India.

Many scholars, however, are generally skeptical of a legislative approach and have instead proposed what Thomas terms a "judicial branch approach." 38 Advocates of this approach argue that the existing text of the WTO agreements already potentially permits contracting parties to regulate imports based on labor rights criteria. ${ }^{39}$ Proponents, such as Robert Howse, believe, for example,

33. The ICFTU is the preeminent international union federation. Originally formed as a counterweight to the communist World Federation of Trade Unions, it now comprises 233 membership organizations from around the world and is regarded as the international voice of organized labor. ICFTU Home Page, http://www.icftu.org (last visited Jan. 23, 2005).

34. Charnovitz, supra note 12 , at 580 .

35. Chantal Thomas, Should the World Trade Organization Incorporate Labor and Environmental Standards?, 61 WASH. \& LeE L. Rev. 347, 374 (2004).

36. Int'l Confederation of Free Trade Unions, Building Workers' Human Rights into the Global Trading System (1999), available at http//www.icftu.org/www/english/els/ escl99BWRGTS.pdf.

37. Id. at 44-46. The only suggested remedy, which is intended as an initial step, is to suspend the access of countries to the WTO's dispute settlement system. Id. at 46. Interestingly, the ICFTU downplays the possible implementation of trade related measures by one country against the other, and emphasizes that its proposal focuses on amending laws, not on imposing trade measures. Id. How the WTO might implement trade measures, however, is a matter of contention. The WTO does not impose trade barriers itself, but rather is a forum to agree on rules of the trading system, and then to adjudicate claims by its contracting members that another contracting member has violated those rules by implementing an illegal trade barrier.

38. Thomas, supra note 35 , at 357.

39. Id. at $357-58$. 
that the public morals exception of Article XX of GATT ought to be understood to include human rights, including core labor rights. ${ }^{40}$

Yet others believe that both the legislative and judicial approaches are unworkable and would opt instead for a politically negotiated solution outside of the regular WTO framework. Andrew Guzman, for example, has argued that the WTO ought to create a separate negotiating forum within which interested contracting members may negotiate special labor rights provisions outside of the general WTO framework but still have recourse to the WTO's dispute settlement system if desired. ${ }^{41}$

While debates over the relative merits of these different approaches continue, the reality is that opposition to linkage by developing countries means there is no possibility in the near future of a workers' rights clause being adopted by the contracting parties. In order to make progress, scholars and advocates need to better understand the following question: Why do many of the developing countries oppose linkage, particularly in the WTO? ${ }^{+2}$ Some scholars and writers have attempted to address arguments put forth by developing countries. Clyde Summers, for example, has highlighted concerns about protectionism, sovereignty, and capital flight. While taking issue with these concerns, he also finds them "not wholly groundless." ${ }^{43}$

In the next section I seek to gain some insight to this question by using India as a case study. I will first briefly trace the history of India's opposition to the workers' rights clause during the mid- to late-1990s, and then analyze and categorize the arguments underlying India's opposition to a workers' rights clause while putting them in historical context.

40. See Robert Howse, The World Trade Organization and the Protection of Workers' Rights, $3 \mathrm{~J}$. SMall \& Emerging Bus. L. 131, 142-45 (1999).

41. Guzman, supra note 4, at 888-89.

42. Some scholars and writers have attempted to address arguments put forth by developing countries. Clyde Summers, for example, has highlighted concerns about protectionism, sovereignty, and capital flight. While taking issue with these concerns, he also finds them "not wholly groundless." Clyde Summers, The Battle in Seattle: Free Trade, Labor Rights, and Societal Values, 22 U. PA. J. INT'L Econ. L. 61, 68-80 (2001). Jose M. Salzar-Xirinachs, a South American diplomat, also describes some of the main arguments put forth by Latin American and Caribbean countries opposing trade and labor linkage. These include what he terms "political economy"; "stage of development"; the "logic of trade negotiations"; "considerations of efficiency in achieving negotiating objectives"; and "arguments related to the global architecture of the trading system." Jose M. Salazar-Xirinachs, The Trade-Labor Nexus: Developing Countries' Perspectives, 3 J. Int'L Econ L. $377,380(2000)$.

43. Summers, supra note 42 , at $68-80$. 


\section{India’s Opposition to a Workers' Rights Clause}

\section{A. Forging Domestic Consensus}

On January 1, 1995, India celebrated its long awaited entry into the world trading system by acceding to the newly formed WTO. Bill Jordan, then General Secretary of the ICFTU, marked the event by traveling to New Delhi to win the support of the government and of his affiliate unions for the ICFTU's campaign to include a workers' rights clause in the WTO. ${ }^{44}$ To Jordan's dismay, he was told by union leaders Sanjeev Reddy of the Indian National Trade Union Congress (INTUC) and Umraol Purohit of the Hind Mazdoor Sabha (HMS) ${ }^{45}$ that he should go "talk with the government of India ... [because] [t] ]he employers, the trade unions, and the Indian government were one on the issue of the 'social clause'." "46

Jordan took the advice of Reddy and Purohit and met with Minister of Commerce, Pranab Mukherjee, and Minister of State for Labor, P. A. Sangma. Jordan was told that India would oppose attempts to link trade with labor standards. ${ }^{47}$ Moreover, India intended to organize other developing countries to do the same.

The somewhat unusual tripartite unity between the government, employers, and unions that Jordan confronted was officially forged at the Indian government's meeting of the tripartite Standing Labor Committee in September 1994. There, the government put forward a resolution asking for a unified stance by the government, unions, and employers opposing a workers' rights clause. The resolution passed unanimously. ${ }^{48}$

44. See Saibal Dasgupta, Social Clause Not Acceptable in Any Form, Says India, Bus. Standard (India), Jan. 18, 1995.

45. HMS and INTUC are the only two Indian members of the ICFTU. For a description of Indian unions, see Indian Nat'l Trade Union Cong., Trade Union Movement in the New MiLLENNIUM 3 (2000).

46. Saibal Dasgupta, The Stick That Lost Its Sting, Bus. Standard (India), Jan. 28, 1995.

47. See Gerda van Roozendaal, Trade Unions and Global Governance: The Debate on a Social Clause 137 (2002).

48. Id. at 129. Van Roozendaal reviewed the opposition by Indian unions to a workers' rights clause and argued that Indian unions uncritically supported the Indian government on this issue because the trade unions (1) distrust the international community; (2) have a weak domestic political position; and (3) were disinterested in workers who might have benefited from a workers' rights clause, such as those in the informal sector. Id. at 113-14. 
The government had also established, in August 1994, the Commission on Labour Standards and International Trade chaired by Dr. Subramaniam Swamy. ${ }^{49}$ The Commission's mandate was, in part, to evaluate a workers' rights clause in the WTO and issue recommendations to the Indian government on what its stance should be. The government clearly did not wish to wait for the results of this inquiry, however, and forged ahead with its anticlause stance.

In January 1996, the Commission finally issued a report that called upon the Indian government to adopt a more moderate position on the social clause, seek international funds to abolish child labor, and forge international consensus on the matter. ${ }^{50}$ However, the government never released the controversial report. Some suspect that this is because the report took a position contrary to the government's position, was criticized in the press, and was criticized by one of its own members, S.L. Passey of the Congress-Party-affiliated union INTUC, who published a separate critique of the Commission's conclusions. ${ }^{51}$

\section{B. Opposition in Civil Society}

However, it was not only unions, government, and employers that were opposed to the workers' rights clause. Other influential segments of civil society, including the media and nongovernmental organizations (NGOs), also took strong positions against it.

India's entry into the WTO and the increasing attention paid by the Indian government to the workers' rights clause issue sparked the media's interest in the beginning of 1995. Major newspapers around the country began to print a slew of editorials that, by and large, opposed the workers' rights clause, arguing that it was motivated by bad faith and was not in the best interests of India. In Kolkata, The Telegraph ran an editorial entitled "Clause and Fangs," which condemned the workers' rights clause as "motivated by simple economic fears: cheap third world imports flooding the first world in a liberalized global trading system." ${ }^{2}$ The prominent Chennai newspaper, The Hindu, ran an editorial that

49. Id. at 129-31.

50. Id at $129-30$.

51. Id. at 130. The committee chair, Subramaniam Swamy, eventually published his own book on the WTO and labor rights in which he argues that India might be a net gainer should a social clause be implemented because labor rights non-compliant competitor countries such as China would be forced to compete on an equal footing. Subramaniam Swamy, India's Labour StanDARDS AND THE WTO Framework (2000).

52. Clause and Fangs, The Telegraph (India), Jan. 23, 1995. 
read, "Here is protectionism in its new garb aiming to strike at the main competitive advantage of the poorer countries, namely, the relatively cheap labour." ${ }^{53}$

Perhaps as a means of supporting their opposition to the workers' rights clause, newspapers made special efforts to favorably report on opposition from non-Indian sources, such as the Association of Southeast Asian Nations (ASEAN), ${ }^{54}$ the U.K.'s Tory government, and the United Nations Conference on Trade and Development (UNCTAD)..$^{55}$

Arguments in support of a workers' rights clause were generally given less coverage, and evidence that the impact of a workers' rights clause might not necessarily be to the detriment of India's economy was largely discounted. In April 1995, for example, a preliminary draft of what was to become a well-publicized report by the Organisation for Economic Cooperation and Development (OECD) suggested that there existed a correlation between levels of respect for core labor rights enforcement and higher trade flows. ${ }^{56}$ The Indian press also reported that the report criticized India's level of respect for labor rights. The Mumbai-based newspaper, Indian Express, ran an article covering the release of this preliminary draft and made no secret of its point of view by dismissing the report's conclusions as being "without evidence."

At least one newspaper, however, was not so sanguine about opposing the social clause. The Business Standard analyzed what would actually substantively be included in a workers' rights clause and, approaching the issue with a little more nuance, ran an editorial suggesting that "the advantage of India opposing the 'social clause' is none too clear except in the obviously contentious area of minimum wages... [but] wages are not currently on the agenda." 58

Both labor-oriented NGOs and non-labor-focused NGOs also opposed the trade and labor linkage, although there was not as much consensus among them as there was among labor unions. One of the most active NGOs on the issue was the Consumer Unity and Trust Society (CUTS), a consumer-rights group that established a trade-policy program in which fighting the social clause was a

53. Protectionism Invading I.L.O.?, THE Hindu (India), Jan. 23, 1995, at 15.

54. E.g., Bandar Seri Begawan, Asean Against Linking Trade with Labour Issues, Bus. Standard (India), Aug. 3, 1995.

55. UNCTAD Against Trade, Labour Linkage, The Hindu (India), Sept. 12, 1995, at 16.

56. Org. for Econ. Co-operation and Dev., International Trade and Core Labour StanDARDS 13, 34-36 (1996).

57. Chitra Subramaniam, India Branded Anti-Labour Without Much Evidence at Hand, Indian Express, Apr. 12, 1995.

58. Editorial, Why Fear the Social Clause?, Bus. Standard (India), Jan. 23, 1995. 
major policy priority. ${ }^{59}$ The Center for Education and Communication (CEC), a prominent NGO that is closely associated with independent unions and researches workers' rights issues, organized in March 1995 a forum on the social clause with participants from NGOs, trade unions, and academia. The newspapers reported that, while there was some disagreement between NGOs and unions on the merits of supporting the social clause, everyone agreed the clause was motivated by protectionist Western goals, and most believed that it should be opposed. ${ }^{60}$ In October 1995, the CEC organized a follow-up meeting, in Bangalore, to its original conference on the social clause, where it issued another anti-social-clause statement. As an alternative to trade-related measures, the CEC advocated a market-based approach, recommending the creation of a national labor body that could accredit products made in compliance with international labor standards such that consumers could decide whether or not to purchase the product. ${ }^{61}$

Even a representative of the United Nations Children's Fund (UNICEF), a U.N. agency unlikely to take an official position on the matter, was reported (perhaps misreported) by the Times of India to oppose linkage in an article entitled "UNICEF Abhors Social Clause Linkage." Stephen Lewis, special representative of the executive director of UNICEF, was quoted to have said, "The social clause issue is loaded with so many other motives. The mention of the trade linkage itself evokes strong reactions in the form of protectionism or neo-colonialism. So how can international pressure be kept up at the point of the gun?"62

\section{Forging International Consensus}

While the Indian government was successfully forging consensus between employers, unions, and the state, and winning the support of civil society, it was

59. For a list of anti-linkage publications by CUTS, see CUTS Centre for International Trade, Economics \& Environment (CITEE), http//www.cuts-international.org/citee-pub.htm\#_Trade_ and_Labour (last visited Jan. 23, 2005).

60. See B. S. Nagaraj, NGO's, Unions Divided on Linkage of Social Clause to Trade Pacts, Indian Express, Mar. 24, 1995; Activists Debate Social Clause, Mainstream (India), May 6, 1995, at 11.

61. Labour-Ecologists' Meet Rejects WTO Trade Clause, The Pioneer (India), Oct. 31, 1995; see Statement from the Second National Consultation on Social Clause in Multilateral Trade Agreements, Bangalore Consultation on Social Clause in Multilateral Trade Agreements, Bangalore, India, October 27-29, 1995, reprinted in Labour, Environment and Globalisation 181, 182 (J. John \& Anuradha M. Chenoy eds., 1996).

62. Inder Sawhney, UNICEF Abhors Social Clause Linkage, Times of INDiA, Jan. 24, 1995. 
also organizing opposition to a workers' rights clause among developing nations in order to defeat it in the WTO. The developing countries had already voiced opposition to labor and trade conditionality in other forums. ${ }^{63}$ But the Fifth Conference of Labor Ministers of Non-Aligned and Other Developing Countries, which took place in January 1995 in Delhi and was held just after the creation of the WTO and India's entry into it, provided India with an opportunity to take a leadership role on the issue. The conference brought together eightyfive developing countries. India was elected chair, and in keeping with its traditional leadership role in the Non-Aligned Movement and the G-77, other nations looked to it for guidance on the trade and labor issue. ${ }^{64}$ Indeed, India took a leadership role and helped organize the participants to issue a statement opposing trade and linkage. The conference issued a statement known as the "Delhi Declaration," which proclaimed the conference's unanimous opposition to a social clause, notably describing the clause as coercive and economically harmful to the workers it would purport to benefit. The statement reads in part:

We are deeply concerned about the serious post-Marrakech efforts at seeking to establish linkage between international trade and the enforcement of labor standards through the imposition of the social clause. [Instead], [a]ction at the national level should be pursued by each country as considered appropriate to its own socio-economic conditions without any form of coercion such as that which the application of the social clause may impose. Such coercion ... also will negate the benefit which the liberalization of trade is intended to bring about, thus aggravating further at least in the developing countries the existing problems of unemployment and distress. ${ }^{65}$

63. VAN RóozendaAL, supra note 47, at 135 (In 1994, “[d]uring a meeting of the United Nations Economic and Social Commission of Asia and the Pacific (ESCAP), developing countries agreed that labour issues should not be linked to trade."). The Fifth Ministerial had also addressed the issue at its Fourth Conference in Tunis.

64. See generally id. at 114. The G-77 is the largest coalition of developing countries in the United Nations. Its aim is to promote its collective economic interests and enhance its collective negotiating capacity within the U.N. system. See Group of Seventy-Seven at the United Nations-General Information, http://www.g77.org/main/main.htm (last visited Jan. 16, 2006).

65. See Fifth Conference of Labour Ministers of Non-Aligned and other Developing Countries Draft Delhi Declaration, Draft Delhi Declaration art. 5.1-2, reprinted in Center for Education and Communication, Social Clause in Multilateral Trade Agreements 161 (1995). 
With this declaration, the labor ministers intended, in the words of one reporter, to "destroy the moral underpinnings of the 'social clause' idea which has enabled Western democracies to sell it to their electorate." 66

After the successful Delhi Conference, the Indian government increased the intensity of its campaign to recruit other developing countries in opposing the social clause. At the November 1995, G-15 summit in Buenos Aires, Prime Minister Narasima Rao strongly urged other developing countries to stand united in opposing a social clause. Instead of a social clause, he argued, they should encourage development assistance from the industrialized countries. ${ }^{67}$

India brought this momentum to the WTO's 1996 Ministerial Conference in Singapore, where some developed countries, notably the United States and France, pushed for linking trade and labor standards ${ }^{68}$ Once again, the Indian press lambasted the attempts by some countries to discuss the labor and trade connection, with headlines such as "WTO Talks Mired in Peripheral Issues," making clear the press's antilinkage position. ${ }^{69}$ Opposition from developing countries to the inclusion of labor rights on the agenda culminated in the withdrawal of an oral invitation to ILO Director General Michael Hansenne to give a presentation to the Ministerial. ${ }^{70}$ Bill Jordan was reportedly not very happy about this development and accused "vested interests" of keeping out Hansenne in order to prevent any possibility of giving legitimacy to the idea of linkage. ${ }^{71}$ In a much discussed compromise move, the contracting parties issued a final declaration supporting international core labor standards, while insisting that the standards stay out of the domain of the WTO and instead remain in the jurisdiction of the ILO. It read:

We renew our commitment to the observance of international recognized core labour standards. The International Labour Or-

66. Saibal Dasgupta, Jt Strategy to Scuttle Social Clause, Bus. Standard (India), Jan. 23, 1995.

67. PM Asks Developed Nations Not to Pursue Social Clause, Bus. Standard (India), Nov. 7, 1995; Kavitha Rao, Third World May Be Stuck with Unrealistic Labour Norms, Econ. Times (India), Nov. 20, 1995.

68. Virginia A. Leary, The WTO and the Social Clause: Post-Singapore, 8 Eur. J. INT'L L. 118,119 (1997).

69. Swaminathan S. Anklesaria Aiyar, WTO Talks Mired in Peripheral Issues, Econ. Times (India), Dec. 12, 1996. But see Tasha Banerjee, Clause and Effect, Econ. Times (India), May 31, 1996 (questioning the motives of Indian union opposition).

70. Leary, supra note 68 , at 119.

71. V. Jayanth, The Link Between Trade and Labour Standards, THE HINDU (India), Dec. 7, 1996, at 11. 
ganization (ILO) is the competent body to set and deal with these standards, and we affirm our support for its work in promoting them. We believe that economic growth and development fostered by increased trade and further trade liberalization contribute to the promotion of these standards. We reject the use of labour standards for protectionist purposes, and agree that the comparative advantage of countries, particularly low-wage developing countries, must in no way be put into question. In this regard, we note that the WTO and ILO Secretariats will continue their existing collaboration. ${ }^{72}$

Yet even this language was considered too strong for the South Asian block of countries. India, Pakistan, and Sri Lanka opposed the statement, but were forced in the end to concede, once other countries such as Malaysia accepted it as a compromise position. ${ }^{73}$

The next WTO Ministerial Conference, in Geneva, was less contentious, as labor rights were not prominently on the agenda. But, in response to anti-WTO protests and world financial crises in Asia and Latin America, then-WTO Director-General Renato Rugiero made comments that were interpreted by some to make space within the WTO for labor rights linkage. These included remarks that "the WTO needed to 'give answers to issues of very real public concern,' including 'social conditions' and 'employment'." "74

\section{Winning the Battle in Seattle}

It was the 1999 Seattle Ministerial-known as the "Battle in Seattle" due to the extensive, and occasionally militant, protests by a diverse range of anti-

72. World Trade Org., Singapore Ministerial Declaration of 13 December 1996, WT/MIN(96)/ DEC/W, 36 I.L.M. 218 (1997), available at http://www.wto.org/english/thewto_e/minist_el min96_e/wtodec_e.htm.

73. Anjuli Bhargava, India, Pak Forced to Accept Labour Issue Reference, Bus. Standard (India), Dec. 12, 1996. See also Swaminathan S. Anklesaria Aiyar, India Falls in Line on Labour Norms, Investment Study, Econ. Times (India), Dec. 13, 1996.

74. See Nigel Haworth, Steve Hughes \& Rorden Wilkinson, The International Labour Standards Regime: A Case Study in Global Standard Setting and Regulation 5 (Bristol Univ. Econ. \& Soc. Research Council Future Governance Programme \& Univ. of Oxford, Working Paper in Economic Geography No. WPG 04-10, 2003), available at http://www.geog.ox.ac.uk/research/wpapers/ economic/wpg04-10.pdf. 
WTO protestors - that was to become infamous and that marked a turning point in the social clause debate. ${ }^{75}$

One of the Clinton administration's priorities at the meeting was to establish a working group on core labor standards and trade within the WTO. ${ }^{76}$ What particularly irked the developing countries was an apparently off-the-cuff remark in which President Clinton told the press that he would support the use of trade sanctions if a country violated core human rights. ${ }^{77}$ India vehemently opposed any effort to create any link between the WTO and labor issues and accordingly opposed the working group proposal. As at the 1996 Singapore Ministerial, the Director General of the ILO, now Joan Somavia, had been invited to address participants at the meeting. Once again, India sharply opposed the invitation, in order not to legitimize the link between labor and the WTO. ${ }^{78}$ The Indian press continued its antilinkage coverage of the debate with headlines such as "WTO Talks Mired in Peripheral Issues," 79 and "US Thrusts Labour Agenda on the Developing World." 80

Despite India's objections to the working group or any other mechanism to discuss labor rights in the WTO, the WTO posted on its website that the contracting parties nevertheless decided to establish a "working group on labor" chaired by Costa Rican Vice Minister Anabel Gonzalez. ${ }^{81}$ The Indian delegation was reportedly furious at this development. The delegation still participated in the December 3, 1999 meeting of the working group, but when asked if a proposal on labor standards would be acceptable if all other Indian demands were met on other issues, Minister of Commerce Murasoli Maran conveyed the vehemence of India's opposition to linkage when he stated, "No, I cannot drink a drop of poison." ${ }^{82}$ Later, Mike Moore, the WTO Director General, claimed that the nomenclature "working group" was inaccurate, and that in fact the group was really just a "sub-group" of the working group that was working on the issues raised at the

75. For an analysis of the Seattle Ministerial, see Summers, supra note 42.

76. David E. Sanger, President Chides World Trade Body in Stormy Seattle, N.Y. Times, Dec. 2, 1999 , at A1.

77. See David E. Sanger, The Shipureck in Seattle, N.Y Times, Dec. 5, 1999, at A26.

78. Sheila Mathrani, ILO Chief Heads for Seattle to Explain Labour Issues, Econ. Times (India), Nov. 24, 1999.

79. Aiyar, supra note 69. But see Banerjee, supra note 69 (arguing India is squandering an opportunity to level the playing field with other developing countries).

80. US Thrusts Labour Agenda on the Developing World, The Statesman, Dec. 3, 2000.

81. WTO Denies Setting Up Labour Standards Work Group, Asia Pulse, Jan. 13, 2000.

82. Narendar Pani, Working Group to Study Labour-Trade Link, Econ. Times (India), Dec. 4, 1999. 
Singapore Ministerial session. Indian officials were not convinced, however, and were quoted as saying that Moore's clarification was just an "afterthought." ${ }^{83} \mathrm{In}$ deed, no working group on labor currently exists in the WTO.

The failure to make any headway in Seattle on trade and labor standards linkage marked both a severe blow to social clause advocates and, perhaps, a stinging defeat. The developing countries managed to successfully prevent the creation of any mechanism within the WTO to discuss labor issues. That accomplishment, combined with a newly elected conservative U.S. administration in 2001 that was hostile to linkage, quelled any momentum to include a workers' rights clause in the WTO. As a result, the social clause debate largely died down in India after Seattle, although newspapers would still print the occasional editorial and op-ed piece. The WTO Doha Ministerial Conference, in November 2001 , notably did not include the social clause issue on the agenda, and the Doha Declaration only reiterated the 1996 Singapore statement, reaffirming that the contracting parties would work with the ILO on the social dimensions of globalization. ${ }^{84}$ Effectively, the campaign for a workers' rights clause was dead.

\section{E. The Arguments ${ }^{85}$}

I have shown that, far from the workers' rights clause being a fractious and controversial issue within India, there was general consensus against trade and labor linkage, even among unions and workers' rights advocates. In this section, I describe and categorize the arguments used by Indian opponents of the workers' rights clause. My core project here is to categorize the arguments so as to aid scholars and advocates in structuring the way they think about linkage. While I do not directly critique the merits of each of the arguments, partial critiques will emerge as I put the arguments into political and historical context. Additionally,

83. See No'Role for NGOs in Dispute Settlement, Says Moore, The Ptoneer, Jan. 13, 2000.

84. See World Trade Org., Ministerial Declaration of 14 November 2001, WT/MIN(01)/DEC/ 1, 41 I.L.M. 746 (2002), available at http:/www.wto.org/english/thewto_e/minist_e/min01_e/ mindecl_e.pdf.

85. I conducted fifteen formal interviews for this section in 2001 , as well as a number of less formal, "conversational" interviews with unionists, workers, journalists, businessmen, government officials, and others. I chose the interviewees based on influence, representativeness, and diversity of institutional affiliation. The small sample size means that none of the results of these interviews should be considered statistically informative on any particular issue. Rather, my goal was to gather a range of ideas and opinions on the workers' rights clause that would help me understand the issues from the point of view of Indian actors. 
it is important to note that I do not attempt to describe every argument, legitimate or not, that might be raised in opposition to a workers' rights clause. My goal, rather, is to highlight and categorize those arguments that arise most frequently within the Indian context.

Arguments used against the workers' rights clause within the Indian debate can be categorized broadly into three categories: economic, political, and structural. ${ }^{86}$ In my typology, an economic argument is one that critiques a workers' rights clause based on its economic impact on the Indian economy. A political argument addresses the proper balance between domestic and international regulatory jurisdiction, as well as ideological and philosophical approaches to economic organization. A structural argument addresses questions such as the legal and strategic effectiveness and appropriateness of using particular institutions and mechanisms to protect workers' rights.

\section{Economic Arguments}

The most commonly articulated argument is an economic one, i.e., that a workers' rights clause will have the effect of reducing trade and, as a result, employment. Moreover, it is argued, the subjective intent of Western parties is not necessarily to better the lot of Indian workers, but rather to protect domestic industry and jobs. Protectionism is probably the central issue for the government and employers and one of the most important issues to unions and workers' rights advocates. ${ }^{87}$

\section{a. Protectionism in Current Context}

The belief that protectionism motivated Western moves for a social clause was prevalent among India's trade unions, including both the central unions

86. Two scholars have attempted to analyze arguments by Indian opposition to linkage, focusing primarily on union opposition. Gerda van Roozendaal has analyzed the Indian union governmental opposition to a workers' rights clause, citing: (1) distrust of Western "motives"; (2) the lack of compatibility between international standards and India's level of development; (3) the lack of effectiveness of a social clause; and (4) sovereignty claims. See VAN RoozendaAL, supra note 47, at 124-26. Rohini Hensman, a Mumbai-based scholar, has argued that the opposition by unions and the Left to the workers' rights clause is rooted in (1) opposition to "globalization" often based on economic and cultural nationalism; (2) opposition to the WTO as an institution; (3) the belief that labor standards are not related to trade and that the West will use these in a protectionist manner that violates national sovereignty; and (4) concerns about how a workers' rights clause might be implemented. See Rohini Hensman, World Trade and Workers' Rights: In Search of an Internationalist Position, 33 Antipode 427 (2001).

87. See Van Roozendaal, supra note 47, at 124; Hensman, supra note 86, at 427. 
that are affiliated with political parties, and the independent ones that operate without affiliation. ${ }^{88}$ P. K. Ganguly, a leader of the communist Centre of Indian Trade Unions (CITU), sums it up succinctly: "[T]he attempt to include [a] social clause in multilateral trade is essentially to introduce unilateral non-tariff protectionist barriers to multi-lateral trade." ${ }^{89}$ The General Secretary of CITU, M. K. Pandhe, reaffirmed this view in an interview noting,

A social clause will not get us a better price for our products. What you will find is all the advanced countries have their trade blocks in the WTO. These trade blocks are there to promote their own economies. They are developing a policy of protectionism, while in the developing countries we are competing with each other. ${ }^{90}$

INTUC, the politically-centered union aligned with the Congress Party, noted in its document "Trade Union Movement in the New Millennium," that "[t]he developed countries ... indulge in protectionism of their self-interests in the name of fixation [on] labour standards, child labour, human rights, environmental concerns, etc., unilaterally to hit the labour-intensive and traditional sectors of developing countries and thus deprive the livelihood of the masses." ${ }^{11}$

The government also relies heavily on the protectionist claim in its opposition to a workers' rights clause. ${ }^{92}$ The Delhi Declaration, quoted above, is one

88. India's trade union movement is dominated by five major trade union centers. These central trade unions are constituted by smaller unions, often plant or worksite based, that are affiliated with the trade union center. The trade union centers are also, with one major exception, affiliated or closely associated with political parties. INTUC, for example, has traditionally been affiliated with the Congress Party. The Bharatiya Mazdoor Sangh (BMS) is aligned with the Bharatiya Janta Parishad (BJP), while the All India Trade Union Congress (AITUC) is affiliated with the Communist Party of India (CPI), and the Centre of Indian Trade Unions (CITU) is affiliated with the CPI (Marxist-Leninist). The Hind Mazdoor Sabah (HMS) has traditionally been nonaligned, although it has a generally democratic socialist bend and, like INTUC, is a member of the International Confederation of Free Trade Unions. Smaller independent unions not affiliated to parties or trade union centers exist throughout the country, but they are particularly concentrated in Mumbai.

89. P. K. Ganguly, Labour Rights and National Interests, in Labour, Environment and GlobalISATION, supia note 61 , at $40,42$.

90. Interview with M. K. Pandhe, Gen. Sec'y, Ctr. of Indian Trade Unions, in New Delhi, India (Aug. 2, 2001).

91. Indian Nat'l Trade Union Cong., supla note 45, at 3 (2000).

92. See VAN RoOzendaAl, supra note 47, at 127. 
expression of this $;{ }^{93}$ while the government's Ministry of Commerce, in its online newsletter, has written:

India's position along with that of many developing countries has been that it is fully committed to the observance of labour rights and promotion of labour welfare through its domestic policies. However, the issue of labour standards at the international level can be appropriately addressed only in the ILO and not in the WTO. The use of trade measures to enforce labour standards is a protectionist device and has to be rejected. ${ }^{94}$

Employers also highlight protectionism as a core concern. As the owner of one of Bangalore's largest apparel manufacturers told me, employers largely see the social clause as a "discriminatory tool," $"$ and believe that developed countries primarily wish to protect their own industries. ${ }^{96}$

Even those who support a social clause, or at least advocate exploring the issue, are skeptical of the West's motivations. Sujata Gothaskar, a Bombay tradeunion activist who does not oppose a workers' rights clause, claimed that "none of us feel that the Western unions are particularly concerned with child labor; just that they are protectionist."

India has good reason to be suspicious of the U.S. and Western governments' motives. Indeed, eliminating the rampant protectionism that marked the trading system was the primary reason why a system of international trade governance came into existence. In what scholars Robert Howse and Michael Trebilcock refer to as the "New Protectionism," 98 developed countries increasingly imposed nontariff barriers to trade through, inter alia, countervailing duties, quotas, and voluntary export restraint agreements in order to protect domestic industries against the economic threat of the newly industrialized

93. See sources cited supra note 65 and accompanying text.

94. Labour Standards - The Social Clause, INDIA \& THE WTO (Gov't of India Ministry of Commerce, New Delhi, India), Sept. 1999, at 6, http://commerce.nic.in/wto-sep.pdf.

95. Interview with Sumeer Hinduja, Group Dir--Human Res., Gokaldas Images, in Bangalore, India (July 29, 2001).

96. Interview with Jagdish Hinduja, Managing Dir., Gokaldas Images, in Bangalore, India (July 29, 2001).

97. Interview with Sujata Gothaskar, Trade Union Activist, in Mumbai, India (Aug. 17, 2001).

98. Michael J. Trebilcock \& Robert Howse, The Regulation of International Trade 21 (2d ed. 1999). 
countries. ${ }^{99}$ An example of this is the now-expired Multi-Fiber Arrangement (MFA), ${ }^{100}$ which had permitted developed countries to place quotas on the import of textiles and apparel. The allowance of quotas was an exception to the GATT's general prohibition against quotas. ${ }^{101}$ Western countries were granted the ability to negotiate bilateral agreements imposing specific quotas for different kinds of garments and apparel..$^{102}$ Industries and workers in those industries gladly supported these moves in order to protect their businesses and jobs.

\section{b. Protectionism in Historical Context}

The presumption that linkage is motivated by protectionist intent is also historically rooted in India's economic and colonial history. Exploring this history will help elucidate the issues facing contemporary scholars and decisionmakers and perhaps shed light on the roots of opposition by other developing countries that share similar colonial histories.

Scholars of Indian labor and economic history often note that Indian labor legislation has its genesis in a colonial-era set of laws originally advocated for by British textile interests. A jit Roy, for example, points to one of the original pieces of labor legislation as an exercise in protecting British textile mills in England. ${ }^{103}$ Roy claims that while the Indian Factories Act of 1881 was ostensibly enacted by the British in order to guarantee minimum working conditions for workers in the textile mills of Bombay, the real impetus behind the law was to protect British mills from cheap imports. ${ }^{104}$ Economic historian Dietmar Rothermund supports this view, writing that " $[\mathrm{t}]$ his act was not passed for philanthropic reasons, but at the insistence of British industrialists, who had to put up with similar restrictions at home." 105

99. Id.

100. Agreement Regarding International Trade in Textiles, Dec. 20, 1973, 25 U.S.T. 1001, 930 U.N.T.S. 162.

101. General Agreement on Tariffs and Trade art. XI, Oct. 30, 1947,61 Stat. A-11, 55 U.N.T.S. 194.

102. The MFA, which expired on January 1, 2005, was replaced by the Agreement on Textiles and Clothing. The latter called for the end of quotas on clothing and textiles as of January 1, 2005. Agreement on Textiles and Clothing, GATT B.I.S.D. (1994), available at http://www.wto.org/ english/docs_e/legal_e/16-tex.pdf.

103. Ajit Roy, Globalisation and the World Working Class, in Labour, Environment and GlobalIsation, supra note 61 , at 33, 35-36.

104. Id. at 35.

105. Dietmar Rothermund, An Economic History of India: The Colonial Period to 1991, at 51 (2d ed., Routledge 1993). 
While Rothermund and Roy are willing to ascribe a singular causality and motivation behind the passage of the law, some historians argue that, although there was indeed pressure for the creation of labor law legislation from British textile interests, there was a multiplicity of constituencies with a variety of interests supporting passage of the labor law. Prominent among these were English and Indian philanthropists who were particularly concerned with the welfare of child and female workers. ${ }^{106}$

Interest in these issues by social reformers was further fueled in 1873 , when the Bombay government issued its Administrative Report for 1872-73, in which it brought to public attention the long working hours of Bombay textile and cotton workers, focusing particularly on child and women's labor. ${ }^{107}$ What resulted was the 1881 Factories Act, but it provided only limited workplace regulations that focused on child and women workers.

The passage of this law, however, provided Indian factory workers inspiration to organize for better working conditions and for labor legislation more farreaching than the 1881 law. Between 1882 and 1890, several strikes took place around the country out of which was created the Bombay Millhands Association under the leadership of N. M. Lokhande. ${ }^{108}$ One of Lokhande's primary objectives was to improve the 1881 legislation by including provisions for a weekly holiday, a "noontide" recess, limitation of working hours, prohibition of undue delay in payment of wages, and compensation for accidents. ${ }^{109}$ In a strange alignment of interests between Indian unions and British manufacturers, the Manchester Chamber of Commerce also agitated for passage of a stricter law, albeit for protectionist reasons. ${ }^{110}$ What resulted, in 1891, was an amended law that provided for more rigorous working-hour protections, a weekly holiday, and a grant of power to local governments to make health and safety regulations. ${ }^{11}$ Even after the passage of the 1891 Factories Act, agitations for more extensive working-hour regulations continued by Indian workers and by British

106. See Rajani Kanta Das, History of Indian Labour Legislation 52 (1941); Sukomal Sen, Working Class of India 46 (2d ed. 1993).

107. See G. Ramanujam, Indian Labour Movement 7 (1986).

108. See id. at 8.

109. T. R. Bhasin, Evolutionary Perspectives of Labour Legislation, and Policy in India 1850 то 1956 , at $5-6$ (1957).

110. Das, supra note 106 , at 53 .

111. Id. at 52-53. 
workers who supported them. ${ }^{112}$ In 1911, advocates succeeded in gaining passage of a newly amended act that reduced hours for all workers. ${ }^{113}$

This brief look at the evolution of one piece of colonial-era Indian labor legislation illustrates that, while Indian stakeholders have historical justification to be skeptical of laws that were generated, at least in part, in order to satisfy protectionist constituencies, it is important to point out that the generative processes of these laws were not necessarily one-dimensional. While British mill owners certainly had, and British workers might and probably did have, protectionist motivations, their interests seemed to align with the professed interests of Indian workers who were agitating for the same in India. ${ }^{114}$ In sum, as scholars such as Rohini Hensman have noted, concerns that the motivations of some actors might be purely self-interested should not obscure the core issues of whether the legislation is desirable. ${ }^{115}$ Indeed, involvement in the crafting of those measures might be the best way to ensure that they are designed to minimize protectionist elements that are not in the interest of the workers that the measures are designed to protect.

\section{Political Arguments}

The second category of arguments against a workers' rights clause is political. Political arguments in India can be subdivided into two types of claims. The first is a sovereignty claim that reflects a concern about the degree to which India maintains control over its own regulatory and governance processes free from foreign international coercion. ${ }^{116}$ In this model, a workers' rights clause constitutes an unacceptable infringement upon India's right to autonomy and selfgovernance because it would circumscribe India's regulatory sovereignty. For example, one factory owner told me that labor conditions are "a process that a country has to undertake itself, not through conditions," indicating a shared opposition to the external imposition of regulation and trade conditionality. ${ }^{117}$

\section{a. Contemporary Political Arguments}

Sovereignty concerns are expressed across stakeholder lines, including by the government, employers, unions, and labor activists. Some of these claims are

112. Id. at 55.

113. Ali Amjad, Labour Legislation and Trade Unions in India and Pakistan 31 (2001).

114. See V. Vivekanandan, Outright Rejection or Strategic Use?, in Labour, Environment and Globalisation, supra note 61, at 143, 150-54; Hensman, supra note 86, at 437.

115. See Hensman, supra note 86 , at 437.

116. See id. at 430; VAN RoozendaAl, supra note 47, at 125-26, 127-28.

117. Interview with Jagdish Hinduja, supra note 96. 
based in nationalism, although a union leader from the CITU, one of the two Communist central trade unions, was careful to note that legitimate sovereignty concerns were to be differentiated from what he described as illegitimate sovereignty claims, such as cultural-and ethnic-based nationalism. ${ }^{118}$

The second political claim is a per se opposition to globalization ${ }^{119}$ and to the international financial institutions with which it is associated, such as the WTO. ${ }^{120}$ While India's economic liberalization is often portrayed as a phenomenon receiving widespread support among all of India's citizens, there are in fact many segments of Indian civil society that are highly skeptical of its implications. According to this point of view, a workers' rights clause in the WTO should be opposed on principle because to accept a workers' rights clause would be to implicitly accept the legitimacy of the WTO, as well as the other international financial institutions and their projects. As N. Vasudevan, leader of an independent union in Mumbai, explains, "[b]ehind the idea of a social clause there is a deep rooted conspiracy aimed at associating trade unions and workers['] organisations into the implementation of structural adjustment plans." ${ }^{21} \mathrm{He}$ adds, "The rule of international capital is now organised through the ... IMF, World Bank and WTO. They stand as the three great pillars of global control." ${ }^{122}$

The left unions are, not surprisingly, the most prominent adherents to the antiglobalization position. For example, CITU's Maharashtra Secretary General, Vivek Monteiro, told me:

[W] don't see the WTO as an impartial body; it's a highly political body and there is a definite agenda behind that. It represents interests of big corporate capitalism. We don't see anything to be gained by labor standards to be operated by a body that is essentially a tool of corporate capitalism. ${ }^{123}$

118. Interview with Vivek Monteiro, Maharashtra Sec'y Gen., Ctr. of Indian Trade Unions, Mumbai, India (July 20, 2001).

119. I use the term globalization in a basic economic sense, and follow Rohini Hensman who defines it as "the increasing integration of national economies into the world economy through the removal of barriers to international trade and capital movements." Hensman, supra note 86 , at 428.

120. See VAN RoozendaAl, supra note 47, at 124 (arguing that unions question the motives of the WTO); Hensman, supra note 86, at 429-30.

121. N. Vasudevan, Workers Should Demand Abrogation of WTO, in Labour, Environment and Globalisation, supra note 61 , at 66, 68.

122. Id. at 67.

123. Interview with Vivek Monteiro, supra note 118. However, leaving open some room for engagement he also noted, "depending on [its] position with unions [the WTO] can evolve." Id. 
The All Indian Trade Union Congress (AITUC), the other communist affiliated union, is also clear in its belief that the WTO is little more than a manifestation and agent of capitalists and multinationals. H. Mahadevan, AITUC Deputy General Secretary, describes the WTO as "the culmination of a 25-yearlong process of forging a new global economy by transnational corporations and banks" and a "totalitarian inter-governmental body."124

It is not only the left, however, that is opposed to the WTO and globalization. The Bharatiya Mazdoor Sabha (BMS) is a labor union that is founded on Hindu nationalist principles and that opposes both communism and foreign multinationals. The BMS, like the communist and left unions, has taken a hardline stance against globalization despite the efforts of its associated political party, the Bharatiya Janta Parishad (BJP), to liberalize Indian markets while it was in power. ${ }^{125}$ Lakshma Reddy, National Secretary of the BMS, told me, "What they say is one country, one world. But in our experience it is about the exploitation of developing countries... That is why BMS has opposed Iglobalization and the WTO] from the beginning." 126

The central trade unions, however, have not been completely uniform in their opposition to globalization. Chandidas Sinha, Secretary of INTUC, said in an interview that INTUC supports trade, ${ }^{127}$ while in its literature INTUC emphasizes that liberalization needs to be accompanied by strong domestic governance that ensures union and worker participation. ${ }^{128}$

\section{b. The Neocolonialism of the Social Clause}

When K. L. Mahendra, Secretary of AITUC and a prominent unionist, writes that " $[\mathrm{t}]$ he trade unions are ... conscious that the developing countries have not come out of the colonial past," 129 we are reminded that the anti-socialclause political arguments are situated within the context of India's colonial experience. For some stakeholders, ranging politically from left to right, globaliza-

124. H. Mahadevan, Speech at the Open World Conference of Labor (Feb. 12, 2000), available at http://www.owcinfo.org/owcnews/owenews 29 .htm.

125. The BJP held power over the governing coalition from 1996 through 2004.

126. Interview with Lakshma Reddy, Nat'l Sec'y, Bharatiya Mazdoor Sabha, in New Delhi, India (Aug. 2, 2001).

127. Interview with Chandidas Sinha, Sec'y, Indian Nat'l Trade Union Cong., New Delhi, India (Aug. 2, 2001).

128. Indian Nat'l Trade Union Cong., supra note 45, at 22-23 (2000).

129. See K. L. Mahendra, The All India Trade Union Congress' Position, in Labour, Environment and Globalisation, supra note 61, at 44, 44. 
tion and the WTO are viewed as engines of Western interests that impose externally dictated financial and political governance.

For example, in a pamphlet entitled "WTO: Moro, Toro, Choro" (WTO: Bend it, Break it, Leave it), BMS founder and right-wing nationalist leader, Datopan Thengri, opposes the WTO and globalization as an encroachment on Indian sovereignty, self-governance, and Hindu culture, and writes with dramatic flourish:

Today a profound and deep challenge is before us. Our country, chained in financial slavery, is being constrained and... pulled tightly.... The reality is that the current manners of conducting our efforts, agriculture, education, research, every jurisdiction is going into the hands of foreigners.... [T] The country will be destroyed. [S] uch a mood has developed that whatever commodity, opinion, or institution is considered best, is from the West. ... These very notions have entered our veins much like those of the intellectuals (rationalists)... [T]his mentality has spread into the entire country's life. ${ }^{130}$

Accusations of a neocolonial agenda and mentality were also made toward the Seattle protestors, workers'-rights-clause advocates, and NGOs, who were sometimes compared to the colonial rulers. One commentator, for example, wrote in a major Indian newspaper:

In sum, they are a new breed of self-righteous imperialists bearing a new White Man's Burden. They have sympathizers in developing countries, just as British imperialists did. Like the old White Man's Burden, the new one also includes some laudable ideals. The question is whether these ideals should be shoved down the throats of poor countries or promoted through persuasion and compensation for the costs they impose. ... ${ }^{131}$

130. Pamphlet from Dattopan Thengri, Bharatiya Mazdur Sabha Founder (April 2001) (my translation).

131. Swaminathan S. Anklesaria Aiyar, India's Comparative Advantage in Agitators, Times of INDiA, Dec. 19, 1999. 
Some commentators have also suggested that Western NGOs and unions supporting a workers' rights clause often universalize their claims without incorporating the viewpoints of, or consulting with, developing world labor activists or NGOs. ${ }^{132}$ Shankar Gopal argues that this was evidenced in Seattle, where Western NGOs and unions made minimal efforts to coordinate or understand the needs and demands of third world actors in formulating their agendas or strategies. ${ }^{133}$ Mark Anner supports this analysis, arguing that the ICFTU's failed campaign to incorporate a workers' rights clause into the WTO at the Seattle round was due in part to an insufficient effort to incorporate Southern voices in forming the ICFTU's policy and campaign. ${ }^{134}$ This sentiment was further echoed in comments made by Gautam Mody, director of the Centre for Workers' Management in New Delhi, who noted that Indian unions were angered by the ICFTU's approach at trying to rally support for the social clause in $1996 .{ }^{135} \mathrm{Ac}-$ cording to Mody, Bill Jordan came to meetings with union leaders to tell them what he and the ICFTU were going to do and get their support for it, ${ }^{136}$ without discussing what might be the approach most amenable to Indian unions. ${ }^{137}$

\section{Structural Arguments}

A third category of anti-social-clause arguments is structural. ${ }^{138}$ These arguments concern, inter alia, the proper institutional capacities and roles of the ILO and WTO; the effectiveness and appropriateness of sanctions as an enforcement mechanism in a workers' rights clause; and the way in which different actors would be involved in the processes of implementing a workers' rights clause.

The first structural claim concerns the proper institutional capacities and roles of the ILO and WTO. First, social clause skeptics claim that the ILO has the most institutional expertise in labor issues, and it is therefore best situated to address them. Yet proponents of this view, such as Vasant Gupte, Director of the

132. See Shánkar Gopal, American Anti-Globalization Movement: Re-examining Seattle Protests, 36 Econ. \& Pol. W KLY. 3226, 3230 (2001).

133. Id.

134. See Mark Anner, The International Trade Union Campaign for Core Labor Standards in the WTO, Working USA, Jul. 31, 2001, at 43.

135. Gautam Mody, Comments at the Conference on Globalization, Labor and South Asian Communities (Nov. 11, 2001).

136. See Dasgupta, supra note 46 and accompanying text.

137. Mody, supra note 135.

138. Rohini Hensman has described some of these arguments as questions of "implementation." Hensman, supra note 86 , at 442 . 
Maniben Kariba Institute, also acknowledge that the "ILO should have stronger teeth and the will to bite." 139 Second is the belief, raised primarily by unionists and labor rights advocates, that the WTO is ill-suited to address labor issues because it is an organization of governments with no representation of civil society. ${ }^{140}$ In support of this, adherents of this view emphasize the fact that unions have no standing to bring complaints to the Dispute Settlement Body. Further, because governments, it is argued, are highly unlikely to lodge a complaint on behalf of workers, the WTO would therefore be largely ineffective as a forum because workers' issues simply would not be raised. The third institutional capacity argument posits that the WTO has already exceeded its mandate and that adding labor rights to the WTO's responsibilities would only exacerbate this problem. This argument is primarily articulated by the Indian government, which is particularly concerned that by allowing labor standards to become part of the WTO's mandate, the flood doors would open to other issues that the developing countries believe ought to stay off the table, such as investment and intellectual property issues. ${ }^{141}$

The second structural argument questions the use of trade sanctions as an appropriate and effective enforcement tool. ${ }^{142}$ Labor and human rights advocates have been particularly keen on the WTO as a forum for linkage, in part because of the economic coercion that the WTO system can facilitate through its capacity to regulate and adjudicate the basis upon which contracting members may discriminate against other contracting members, including based on labor rights criteria. The role of sanction in the debate is reflected by Subramanian Swamy when he writes,

[T] The basic dilemma is that any provision for trade sanctions will meet strong opposition from developing countries because it threatens comparative advantage, while any clause that does not include trade sanctions will not add much to the urgency to correct the default in labour standards, and therefore not be credible to those advocating [for the] Social Clause. ${ }^{143}$

139. Interview with Vasant Gupte, Dir., Maniben Kariba Inst., in Mumbai, India (July 16, 2001). 140. Id.

141. See Van RoozendaAl, supra note 47, at 128.

142. Hensman, supra note 86 , at $431-32$.

143. Swamy, supra note 51. 
First, as Bennet D'Acosta, General Secretary of the Hindustan Lever Union, has stated, a sanctions regime risks harming the people whom it purports to help. ${ }^{1+4}$ This is a version of the argument, put forward by some economists, that sanctions would only decrease the aggregate welfare of workers and harm the people whom a workers' rights clause was intended to benefit. ${ }^{1+5}$ Second, there is a concern that in a WTO sanctions regime, sanctions are insufficiently tailored to punish the actual violators of workers' rights and reward those factories that respect workers' rights. ${ }^{146}$ Because sanctions in a WTO-based workers' rights regime would likely be commodity-based and applied ind ustry wide, and not be factory specific, trade measures are too blunt a tool. ${ }^{147}$ Thus, even factories in a given industry that respect workers' rights would potentially suffer from sanctions imposed by an importing country. Finally, interviewees expressed concern that wealthy countries would wield more power in a sanctions regime because exports to the United States from India are more significant to the Indian economy than U.S. exports to India are to the U.S. economy.

A third category of structural arguments challenges the effectiveness of a workers rights' clause in the Indian context. It is estimated that a high percentage of employment is in the informal, or what in India is often termed the unorganized, sector. ${ }^{1+8}$ This sector primarily produces for the domestic market. Moreover, it has been estimated that only about 10 million workers produce for the export sector altogether in India, although that might double by $2010 .{ }^{149} \mathrm{Be}-$ cause a workers' rights clause would only apply to products made for export, it would impact only a relatively small segment of the Indian workforce and

144. Interview with Bennet D'Acosta, Gen. Sec'y, Hindustan Lever Union, in Mumbai, India (July 17, 2001).

145. See Stern, supra note 32.

146. Interview with Bennet D'Acosta, supra note 144.

147. WTO rules provide that compensation and suspension of concessions must preferably take place within the same sector that has been found to be in violation of WTO rules. See Final Act Embodying the Results of the Uruguay Round of Multilateral Trade Negotiations, annex 2, art. $22 \S 3$, Apr. 15, 1994, 33 I.L.M. 1125, 1239 (1994), available at http://www.wto.org/english/ tratop_e/dispu_e/dsu_e.htm.

148. According to one World Bank report, $73.7 \%$ of non-agricultural labor in India is in the informal sector. Niels-Hugo Blunch et al., The Informal Sector Revisited: A Synthesis Across Space and Time 9 (World Bank, Social Protection Discussion Paper Series No. 0119. 2001), http:// siteresources.worldbank.org/SOCIALPROTECTION/Resources/SP-Discussion-papers/ Labor-Market-DP/0119.pdf.

149. Amiti Sen, Merchandise Exports May Create 20 M Jobs by 2010, Fin. Express (India), Apr. 19, 2005. 
therefore would not have a significant impact on the vast majority of Indian workers. ${ }^{150}$

The final category of structural arguments might be termed "compatibility" issues. This argument cuts to the heart of the International Labor Standards debate and questions whether it is equitable and appropriate to apply a uniform set of standards to countries of differing levels of economic development. ${ }^{151}$ Of particular concern is the special attention given to child labor by the West. ${ }^{152}$ The question of how to address child labor in India is a controversial one. While some argue that child labor would be solved through development and increases in aggregate wealth, others, notably Myron Weiner, have argued that the child labor question is a matter of political will, rather than one of economics, and that child labor only exists in India because of a lack of will of the middle class to stop it. ${ }^{153}$ Whatever the policy perspective, many stakeholders in India believe that Western countries would use child labor as the justification to impose sanctions.

In this section I have broadly outlined the arguments raised by Indian stakeholders in the workers'-rights-clause debate, and have put forward a simple typology to aid scholars and advocates in thinking about what issues need to be addressed. I have not attempted to list every argument for or against trade and labor linkage, but rather have attempted to focus on the ones that are most prevalent.

\section{A New Politics of Linkage?}

To move beyond stalemate on the linkage issue, advocates and scholars must engage more dynamically with the economic, political, and structural objections of stakeholders in the developing world. First, they must focus on reducing the perceived and actual presence of protectionist intent and effect. To that end, clarity about which labor standards or rights would constitute the labor standards mandate is vital, and would help mitigate the concerns that the workers' rights clause is a protectionist attempt to drive up wages and injure India's competitive advantage. Second, political concerns need to be taken into account, and an approach adopted that privileges domestic regulatory control, multi-

150. See, e.g., Hensman, supra note 86 , at 441.

151. Interview with Chandidas Sinha, supra note 127; Hensman, supra note 86, at 437.

152. "None of us feel that Western unions are particularly concerned with child labor, just that they are protectionist." Interview with Sujata Gothaskar, supra note 97.

153. See Myron Weiner, The Child and the State in India: Child Labor and Education Policy in Comparative Perspective 5-6 (1991). 
stakeholder participation, and transparency. There needs to be recognition of the tenor and amplitude of skepticism by some stakeholders about globalization, and an understanding of the colonial frame within which the linkage issue is seen by many countries. Careful stock must also be taken of the proper institutional roles of the WTO and the ILO, for the question as to whether international labor governance ought to fall within the domain of international financial institutions or international labor institutions is not a trivial one. Finally, the fixation, by some, with the sanctions power of the WTO needs to be reconsidered, for, as we have seen, it is highly problematic both on a practical and symbolic level to many in the developing world.

Where, then, does that leave the trade linkage debate? There is little chance of legislative linkage, in the form of a workers' rights clause, occurring in the WTO anytime in the foreseeable future. The Singapore Declaration, reaffirmed at Doha, together with the defeat of any inclusion whatsoever of discussion of the issue at Seattle, has made this clear. Some might still hope that a judicial approach in the WTO is the best opportunity to link the international trade system with labor rights protections. But a judicial approach requires that a country implement a law limiting imports of a product made in a manner that violates workers' rights. If such a labor-related trade measure were to survive a challenge in the WTO, it would be dependent on the interpretive stance of a Dispute Settlement Body that might be composed of the workers' rights skeptics that are part of what Howse has described as an "insider network" ideologically committed to free trade and intuitively opposed to regulation protecting foreign workers. ${ }^{154}$

Bilateral and regional agreements perhaps hold the most promise. The advantage of bilateral and regional agreements is that they are negotiated in context-specific situations and have the consent of signatory countries. But, in recent years, the provisions in bilateral agreements have become less rigorous; ${ }^{155}$ and apart from NAALC, at the time of this writing there has yet to be any actual use of their remedies for labor rights enforcement. ${ }^{156}$ In addition, although bypassing the WTO, most of the labor rights provision formulations in these agreements have followed the violation-complaint-sanctions model of which many developing countries are wary.

154. Robert Howse, From Politics to Technocracy-and Back Again: The Fate of the Multilateral Trading Regime, 96 Aм. J. INT'L L. 94, 104-05 (2002).

155. See Greven, supra note 29 , at 30-31.

156. See id. at 27 (noting that the remedial mechanisms are "as of yet untested" in agreements such as the Jordan agreement). 
While it is beyond the scope of this paper to detail an alternative path for new labor rights approaches in bilateral trade agreements, I propose a few guidelines for a new way forward that takes stock of the new politics of linkage. First, there should be a move away from a sanctions model toward an incentives model. Thus, tariff reductions might be the carrot in return for verified compliance with international labor standards. ${ }^{157}$ Second, labor rights enforcement is no longer purely the domain of state-centered law. Informal and non-statecentered regulation, such as corporate codes of conduct and transparent monitoring by NGOs, have become a new form of enforcing labor rights in which a market for labor-standard-compliant products plays a role, in addition to more traditional state-focused legal approaches, in promoting respect for labor rights. ${ }^{158}$ Trade and labor linkage regimes can utilize these tools of enforcement if integrated creatively, as they have been done, as I describe below, in Cambodia. By focusing on non-state-oriented approaches, some of the political concerns that I have described above might be mitigated. Third, the ILO ought to play a prominent role in the new linkage regimes. We have seen that the ILO is viewed as a trusted and neutral organization by many stakeholders in the developing world. The role of the ILO remains to be determined and is dependent on the specific context in which the ILO is working. It could act, for example, as a neutral arbiter of labor rights compliance in the tariffs-incentive regime in point one. Or, it could be a trusted monitor of violations at the factory level, generating information for the social market for standards as described in point two. ${ }^{159}$

Some of these approaches have already been experimented with in a bilateral textile agreement that was in effect between the United States and Cambodia between 1999 and 2004. ${ }^{160}$ This agreement provided an incentive, by means of quota allowance, for the Cambodian garment industry to be in compliance

157. This tariffs incentives proposal has been put forward by Human Rights Watch. See Human Rights Watch, Deliberate Indifference: El Salvador's Failure to Protect Workers' Rights 95-96 (2003), available at http://www.hrw.org/reports/2003/elsalvador1203/elsalvador1203.pdf.

158. See, e.g., Dara O'Rourke, Outsourcing Regulation: Analyzing Nongovernmental Systems of Labor Standards and Monitoring, 31 PoL'y Stud. J. 1 (2003).

159. See Sandra Polaski, Cambodia Blazes a New Path to Economic Growth and Job Creatıon 10 (Carnegie Endowment for Int'l Peace, Carnegie Papers No. 51, 2004); Kolben, supra note 27 , at $81-82$.

160. Agreement Relating to Trade in Cotton, Wool, Man-made Fiber, Non-Cotton Vegetable Fiber and Silk Blend Textiles and Textile Products Between the Government of the United States of America and the Royal Government of Cambodia, U.S.-Cambodia, Jan. 29, 1999, http:// phnompenh.usembassy.gov/uploads/images/M9rzdrzMKGi6AjfOSIuJRA/uskh_textrile.pdf. 
with Cambodian and international labor law. To determine if the industry was in compliance, the ILO was contracted to monitor Cambodia's garment factories and make public the results of their findings. ${ }^{161}$ Buyers would evaluate companies and make sourcing decisions based in part on the information generated by the ILO. Indeed, some would not do business in a factory that had not been inspected. What was particularly novel about this model was that it combined a state-focused, public law approach of a trade agreement, with a mechanism that generated information for the market for labor rights-compliant garments. ${ }^{162}$ The project was so successful in the view of Cambodia's government, unions, and garment manufacturers that it has garnered funding from the World Bank to continue a monitoring initiative as a means of improving its competitive advantage after the MFA. ${ }^{163}$

Whatever the particular forms international labor rights regulation and trade and labor linkage will take in the future, the new politics of linkage requires a new interaction and engagement with the objections raised by developing countries in the workers' rights clause debate. Otherwise, scholars and advocates will continue to reinvent the wheel ${ }^{164}$ and move nowhere.

161. For more information on this program, see generally Regina Abrami, Worker Rights and Global Trade: The U.S.-Cambodia Bilateral Textile Trade Agreement (Harvard Bus. Sch. Case Study No. 9-703-034, 2004); PoLAsk1, supra note 159; Kolben, supra note 27, at 100-03.

162. Kolben, supra note 27 , at $80-81$.

163. For more information about this program, see Better Factories Cambodia Home Page, http://www.betterfactories.org/.

164. See Charnowitz, supra note 12. 
